\section{REPORT OF A CASE OF MYYOEDEMA.}

BY ARTHUR LATTEY, L.R.C.P. LOND.

Mrs. W. C--, aged fifty-seven, was quite healthy until seven years ago, when she had what she describes as a fit, and was unconscious for more than an hour. The attack was not repeated, but her general health became bad, and a medical man who saw her about that time is reported to have said that she had a diseased heart, a diseased liver, and disease of the spine. The catamenia ceased about a year afterwards, and her health became somewhat better. She keeps a small grocer's shop, lives in an aguish district, and has suffered from ague on one oceasion for more than nine months.

I first saw the patient in November, 1879, when her condition was as follows. The countenance was inexpressive and apathetic, the lips thick and everted, and the angles of the mouth depressed. There was marked oedema of both upper and lower lids, and the complexion was muddy and yellow, with a fixed brickdust-colonred patch on both cheeks. Heart sounds normal, but somewhat feeble. Pulse 68 . Urine : sp. gr. 1024; no sugar, albumen, or deposits. Her principal complaint was of weakness and flatulent dyspepsia being a large tea-drinker, that was not to be wondered at. She improved under bitter tonics-gentian, quassia, \&c.

I was again asked to see her on May 21st, 1882. She has gradually been getting more dull and heavy. She cannot use her tingers well, and has to get her customers to do up their parcels of tea and sugar for themselves; her fingers, too, are visibly thickened. Her face has a very vacant look, and the countenance generally is broadened. Her eyes water a great deal, and her sight is not so good, but the ophthalmoscope reveals nothing unusual. She is constantly dribbling, and at night her pillows get wet through with saliva. During the last year she has become almost completely bald. Her hearing is bad, and there is bleeding from the right ear. Her speech is peculiarly slow and deliberate, but she expresses herself well, and does not stumble in her words. At night, when she takes off her stockings, she can shake the epithelium out of them "just like flour." I could not detect any enlargement of the liver or spleen. The urine is perfectly bealthy, and the heart sounds are as they were more than two years ago. She appears to derive most benefit from ammonia and gentian under their administration her appeiite has improved and she has gained some strength. The disease appears to me to depend upon disordered nutrition, with paresis of the vaso-motor nervous system. The skin generally becomes doughy and dry, and loses its natural oiliness and elasticity. Tactile sensibility is in consequence much diminished, and the faculties sink more or less into a condition of hebetude. Southminster.

\section{SEVERE URAEMIC CONVULSIONS AND COMA TREATED BY INHALATION OF CHLORO- FORM AND SALICYLATE OF SODA; RECOVERY.}

BY THOS. A. J. COCKSEDGE, M.A. CANTAB, SURGEON A.M.D. (H.P.).

ON the 28th of April I received an urgent message to attend the Rev. C. M- He had been under my charge for some weeks as he was suffering from chronic desquama tive nephritis, complicated with asthma. His kidney disease is, I believe, of nine years' standing. I found him semicomatose, and during the day he gradually lapsed into a condition of profound coma. Convulsions came on about 1 P.M.; they occurred at first with intervals of about one hour, and as the day wore on, although less violent, with interv ls of about twenty minutes. His last convulsion took place about midnight. He wa seen by Mr. Martin Coates of Salisbury with me about 11 P. MI. He was then perfectly comatose, the pupils being quite insensitive to light. Mr. Coates considered him to be in a desperate condition, and confess that I quite agreed with the prognosis. However, on visitiog him again after Mr. Coates left $I$ found the convulsions so much less violent that I became more hopeful. The next day there bad heen no recurrence of the spasms, and he steadily progressed towards recovery. The treatment of the case was as follows. Mustard and water was applied to the feet. Turpentine enemata were injected into the rectum. Podophyllin and jalapine were given by the mouth, being introduced throogh a quill. The surface of the body was sponged over with vinegar and water, and profuse diaphoresis was thus induced. Chloroform was administered by inhalation during two of the severest spasms. On the secund occasion, however, I noticed that respiration was with such difficulty re-established that I did not venture on a third administration of this remedy. Before leaving on the morning of the 29th I gave him an enema, almost as hot as I could bear my finger in, of very weak mutton broth, this being the first food which he had taken since his eveniug meal of the $27 \mathrm{th}$. On the 29 th, as soon as he was able to swallow, I gave bim seven and a half grain doses of salicylate of soda in weak milk and water every six hours. I am sorry that full notes of the case were not taken; my excuse for this must be that I was so busy that I really had not the time to make them. I consider that details, unless exact, are worse than valueless.

I am induced to send this case for publication, as Mr. Coates assures me that in an experience of over forty years he has never seen such a severe case of uræmia recover. I may mention that I suggested bleeding from the arm, and that Mr. Coates quite agreed with me about this, but it was not allowed by the family. I notice a case of recovery at Geneva fullowing bleeding, reported in THE LANCET of May 6th. Broadchalke, Salisbury.

\section{THE USE OF MORPHIA HYPODERMICALLY} AS AN ADJUVANT TO CHLOROFORM.

\section{Bx ANDREW S. CURRIE, M.D. EDIN., \&c.}

AN interesting paper "On the Combined Use of Morphia and Chloroform in producing and maintaining Surgical Anresthesia," by Dr. Alexander Crombie, Superintendent of the Medical School, Dacca, Bengal, was published in the Practitioner in December, 1881. This paper does not appear to have attracted the notice it deserved, both on account of its originality and the remarkable results obtained by the method described by the author. Dr. Crombie states as the result of his personal experience that out of about 600 cases in only one was there threatened asphyxia, "and in that instance the usual precautions had been neglected." The method employed is very simple, and consists in the hypodermic injection of morphia immediately after beginning the administration of chlorofurm. I have recently employed a moditication of this plan with the greatest comfort to the patient and to myself. About ten minutes before administering the chloroform I inject a full dose of the liq. morphiæ hypod. (B.P.). The chloroform is freely sprinkled on a piece of lint folded twice, and one dose is as a rule sufficient to induce complete anæsthesia.

Having a day or two ago to open a large abscess of the thigh, in the case of a lady who has been an invalid for the list ten or twelve months, I induced anæsthesia easily and rapidly in this way. The patient, who has repeatedly had chloroform adwinistered for confioements, tooth extraction, \&c., assured me that she had never before taken it with such a total absence of all feeling of discomfort. There was no sensation of suffucation and no trouble with after-sickness, which had on previous occasions proved troublesome.

Lydney, Gloucestershire.

WEST LONDON HosPITAL - The growing usefulness of this charity may be estimated from the fact that in 1862 , two years after its establishment, 82 iu-patients were admitted, whereas last year the number had increased to 611 . At a festival held at Willis's Ronms on the 17th inst. in aid of the funds of the hospital, the chairman, Viscount Enfield, expressed the hope that in the ensuing year the number of beds would be raised to 100 , towards the realisation of which anticiparion, a sum between $£ 900$ and $£ 1000$ was subscribed in the course of the evening. 